\title{
Effects of Chlorinated Benzenes on Diatom Fatty Acid Composition and Quantitative Morphology. I. 1,2,4-Trichlorobenzene
}

\author{
L. Sicko-Goad, D. Lazinsky, J. Hall, and M. S. Simmons \\ Great Lakes Research Division, The Institute of Science and Technology, The University of Michigan, \\ Ann Arbor, Michigan 48109, USA
}

\begin{abstract}
Cells of the diatom Cyclotella meneghiniana were exposed in a closed system to $0.245 \mathrm{ppm}$ 1,2,4-trichlorobenzene. Response to this chlorinated benzene was monitored over a period of 5 days by quantitative ultrastructure and fatty acid percent composition. Over the time period examined, 41 significant morphological changes and 12 significant changes in fatty acid composition were observed. Autophagic-like vacuoles were frequently observed, indicating lysis of cellular constituents. In general, there was an increase in the C20:5 fatty acid, which may be indicative of photosynthetic impairment, since this fatty acid probably substitutes for linolenic acid in diatoms. The most significant numbers of changes were observed after $8 \mathrm{hr}$ of exposure to this lipophilic toxicant, and these changes occurred in membranous organelles. It is suggested that the daily photoperiodic variation in lipid content of phytoplankton may be an important consideration in evaluating effects of lipohilic toxicants.
\end{abstract}

Aromatic compounds account for nearly $50 \%$ of the total synthetic organic chemical production in the United States. Within the general class of aromatic compounds, chlorinated benzenes, phenols, and chlorophenols have some of the highest rates of production. These compounds are used in the production of pesticides, pharmaceuticals, dyes, and detergents. Input to the ecosystem is primarily from industrial and municipal water and agricultural runoff, with some additional input of chlorinated phenols and benzenes by chlorination treatment processes. Benzene, phenol, and their chlorinated derivatives are all on the US EPA priority pollutant list.
The fate of any toxicant is dependent on the source of input and physical-chemical properties of the toxicant as well as the receiving system. Chemical and environmental properties that can affect the toxicity of compounds include, but are not limited to the following: water solubility, vapor pressure, rates of volatilization, hydrolysis, photolysis, sorption-desorption, octanol/water partition coefficients, boiling and melting points, ambient temperature, moisture and humidity levels, wind velocity, biodegradation rates, rates of conjugation, and leaching and/or dispersion characteristics. These properties have been used in models to predict the concentrations and residence times of the pollutant in various components of ecosystems. In aquatic ecosystems, exposure and accumulation may occur as passive uptake or sorption, or by active ingestion of contaminated food sources or abiotic particles.

In general, lipophilic compounds such as pentachlorobenzene which have a high octanol/water partition coefficient and a low water solubility tend to passively bioconcentrate. Estimates of bioconcentration factors (BCF) for such compounds have established a linear relationship between the experimentally determined $\log \mathrm{K}_{\mathrm{ow}}$ or $\log \mathrm{W}_{\mathrm{s}}$ and $\log$ BCF (Neely et al. 1974; Lu and Metcalf 1975). Pentachlorobenzene has a higher bioconcentration factor than the trichlorobenzenes (Geyer et al. 1984; Halfon and Reggiani 1986). However, the presence of chlorine substituents in benzene distorts the aromatic ring and this distortion plays a role in the uptake of chlorobenzenes. For example, Matsuo (1980) found that uptake of hexachlorobenzene by guppies was less than expected and suggested that this was due to the non-planarity of the benzene ring.

The toxicity of 1,2,3-trichlorobenzene (TCB) was greater than 1,2,4-trichlorobenzene in Selanastrum 
(Galassi and Vighi 1981). Williams et al. (1975) found that the extent of metabolism of chlorinated benzenes and potential epoxide formation depended on the number of unsubstituted vicinal carbon atoms. 1,2,3-TCB has 3 free vicinal carbon positions (at 4,5,6) and 1,2,4-TCB has 2 free vicinal carbon positions (at 5,6 ). Thus both compounds have the possibility of epoxide formation and a high extent of metabolism. 1,3,5-TCB and pentachlorobenzene have no free vicinal carbon positions and thus cannot form epoxides. The extent of metabolism of 1,3,5-TCB is low, while it is very low for pentachlorobenzene. The presence of three free vicinal carbon atoms in 1,2,3-TCB may explain the results of Galassi and Vighi (1981).

Another possible explanation for different reactivities among the trichlorobenzene isomers could be explained by the nucleophilic substitution reaction in which the chlorine substituent is replaced by a hydroxyl group. If there is an adjacent chlorine present, a second hydroxyl group is added, forming a diol with subsequent breakage of the carboncarbon bond. Gibson (1976) demonstrated such nucleophilic substitution in bacteria. However, the occurrence of epoxidation and/or nucleophilic substitution is dependent upon environmental conditions. Based on this information, the predicted chemical toxicity would be as follows: $1,2,3-\mathrm{TBC}>$ 1,2,4-TCB $>1,3,5$-TCB $>$ Pentachlorobenzene.

Since there is sufficient reason to believe that a correlation exists between the uptake of chlorinated hydrocarbons by organisms and their lipid content, and since it has been demonstrated that exposure to hydrophobic compounds may result in changes in fatty acid composition, studies were undertaken to determine the effect of selected chlorinated benzenes on diatom fatty acid composition and cell structure and to determine if, under similar controlled environmental conditions, observed sensitivity paralleled that predicted by environmental chemistry. Due to the immense data set generated by these experiments, the data for each chlorinated benzene exposure experiment are being reported separately in the following series of papers. This report presents results of the 1,2,4-trichlorobenzene exposure.

\section{Materials and Methods}

\section{Algal Cultures}

Cyclotella meneghiniana (Bacillariophyceae) clone $\mathrm{CYOH}$ was obtained from Dr. S. S. Kilham of the Department of Biological Sciences at the University of Michigan. The culture was grown in WC medium (Guillard 1975) and placed on a rotary shaker table in a growth chamber set at $20^{\circ} \mathrm{C}$ on a $16 / 8 \mathrm{hr}$ light/dark cycle at $100 \mu \mathrm{Ein} \cdot \mathrm{m}^{-2} \cdot \mathrm{sec}^{-1}$. The cells were subcultured weekly to larger volume flasks to increase cell density for the experiment. For experimental purposes, exponentially growing cells were evenly subdivided between two four-L extracted and acid washed glass stoppered flasks. Cell densities for the three experiments were $50,000+10 \%$ cells $/ \mathrm{ml}$, with the smallest number of cells present in the 1,2,3-TCB exposure experiment. Cells from both exposed and unexposed treatments were withdrawn by a dry air pumping apparatus. For all three trichlorobenzene experiments, $0.245 \mathrm{ppm}$ of the isomer in distilled, deionized water with no added carrier was added to the experimental flasks. This concentration is well below maximum water solubility. To assess the effect of the chlorinated benzene on parameters studied, cells were harvested at the following times after exposure to the toxicants: $10 \mathrm{~min}, 1 \mathrm{hr}, 8 \mathrm{hr}, 24 \mathrm{hr}$, and 5 days. These sampling times also included sampling of the control cultures with no toxicants added. Consequently, control flasks also served as culture manipulation flasks since both exposed and unexposed cultures were handled in an identical manner.

\section{Fatty Acid Analysis}

For fatty acid analysis, $125 \mathrm{ml}$ of culture medium containing cells was withdrawn and filtered through GFC filters. The filter retaining the cells was placed in an aluminum foil wrapped vial containing $3.5 \mathrm{ml}$ methanol/water (7:3) and $5 \% \mathrm{KOH}$ solution. The solution was bubbled with nitrogen and boiled in a $60^{\circ} \mathrm{C}$ water bath for $2 \mathrm{hr}$ to complete deactivation and saponification. The digested mixture was filtered and other organics extracted with $2 \mathrm{ml}$ pentane. The aqueous solution was acidified with $2 \mathrm{ml}$ $2.3 \mathrm{~N} \mathrm{HCl}$ and fatty acids were extracted 4 times with $1 \mathrm{ml}$ pentane. Pooled fractions were washed with $2 \mathrm{ml}$ saturated $\mathrm{NaCl}$ and dried over anhydrous sodium sulfate (Schwarzenbach and Fisher 1978).

To esterify the fatty acids to methyl esters, the solvent was evaporated with nitrogen and the extract redissolved with $5 \mathrm{ml}$ benzene in a vial with a Teflon-lined cap. Boron trifluoride $(0.5$ $\mathrm{ml}$ ) was added and the solution was boiled for $4 \mathrm{~min}$ in a $60^{\circ} \mathrm{C}$ water bath and washed with $10 \mathrm{ml}$ distilled water. Fatty acid methyl esters (FAMEs) were extracted with hexane and dried over anhydrous sodium sulfate (Metcalfe and Schmitz 1961). The pooled extract was concentrated by a nitrogen stream to approximately $10 \mu$.

For quantification of the FAMEs, samples were analyzed on a Varian 3700 gas chromatograph (GC) with a DB5 $(30 \mathrm{~m}$, narrow bore, $1 \mu \mathrm{m}$ film), fused silica column, equipped with a flame ionization detector (FID) and an HP 3900A integrator. The GC/ FID program consisted of the following conditions: Split mode (58:1), injector temperature $=250^{\circ} \mathrm{C}$, detector temperature $=$ $290^{\circ} \mathrm{C}$.

The column temperature program consisted of $4 \mathrm{~min}$ at $225^{\circ} \mathrm{C}$, $4^{\circ} \mathrm{C} / \mathrm{min}$ rate to $280^{\circ} \mathrm{C}$ with a 20 -minute hold. Separation and relative retention times were established with a standard FAME solution consisting of C12:0, C13:0, C14:0, C15:0, C16:1, C16:0, C17:0, C18:3, C18:2, C18:1, C18:0, C19:0, C20:3, C20:2, C20:1, $\mathrm{C} 20: 0, \mathrm{C} 21: 0, \mathrm{C} 22: 1, \mathrm{C} 22: 0, \mathrm{C} 23: 0, \mathrm{C} 24: 1$, and C24:0 fatty acids.

To verify the fatty acids by gas chromatography/mass spectrometry, one of the triplicate samples from each experimental and control sample was pooled and concentrated. The concentrated sample (pooled from 24 individual replicates) and the standard FAME solution were analyzed on a Finnigan 4000 


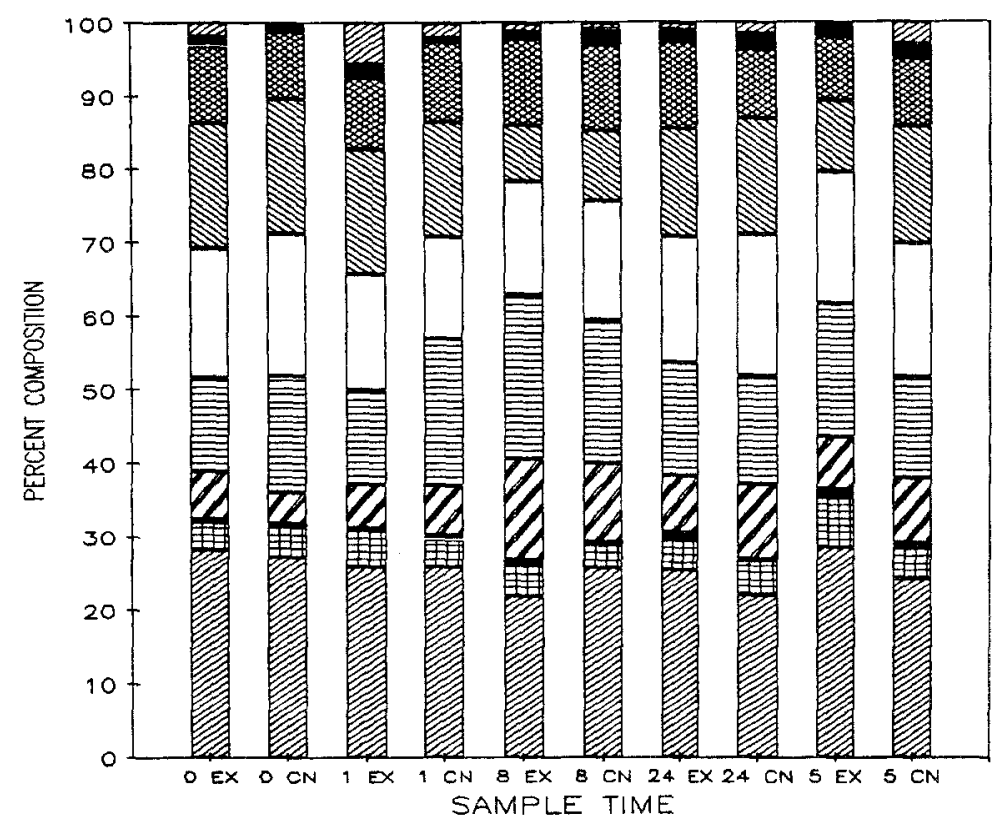

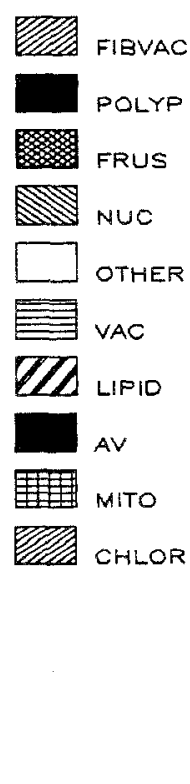

Fig. 1. Percent composition of morphological components for all control $(\mathrm{CN})$ and experimental $(\mathrm{EX})$ treatments. Percent composition is that volume portion of a cell occupied by cellular organelles and compartments identified

Table 1. Relative volumes (\% composition) and numbers per volume of cellular components of Cyclotella menighiniana control cells and cells exposed to $0.245 \mathrm{ppm} \mathrm{1,2,4}$ trichlorobenzene. Values reported are the mean $( \pm 1 \mathrm{~S}$.E.) of a sample size of 25

\begin{tabular}{|c|c|c|c|c|c|c|c|c|c|c|}
\hline \multirow[b]{2}{*}{ Cell Component } & \multicolumn{10}{|c|}{ Experimental Treatment } \\
\hline & $\begin{array}{l}10 \mathrm{~min} \\
\text { Control }\end{array}$ & $\begin{array}{l}10 \mathrm{~min} \\
\text { Exposed }\end{array}$ & $\begin{array}{l}1 \mathrm{hr} \\
\text { Control }\end{array}$ & $\begin{array}{l}1 \mathrm{hr} \\
\text { Exposed }\end{array}$ & $\begin{array}{l}8 \mathrm{hr} \\
\text { Control }\end{array}$ & $\begin{array}{l}8 \mathrm{hr} \\
\text { Exposed }\end{array}$ & $\begin{array}{l}24 \mathrm{hr} \\
\text { Control }\end{array}$ & $\begin{array}{l}24 \mathrm{hr} \\
\text { Exposed }\end{array}$ & $\begin{array}{l}5 \text { day } \\
\text { Control }\end{array}$ & $\begin{array}{l}5 \text { day } \\
\text { Exposed }\end{array}$ \\
\hline Chloroplast $\mathrm{V}_{\mathrm{v}}$ & $\begin{array}{l}26.3 \\
(1.7)\end{array}$ & $\begin{array}{l}27.2 \\
(2.0)\end{array}$ & $\begin{array}{l}25.1 \\
(1.5)\end{array}$ & $\begin{array}{l}25.3 \\
(1.7)\end{array}$ & $\begin{array}{l}24.8 \\
(1.9)\end{array}$ & $\begin{array}{l}21.1 \\
(2.0)\end{array}$ & $\begin{array}{l}21.6 \\
(1.5)\end{array}$ & $\begin{array}{l}24.6 \\
(1.7)\end{array}$ & $\begin{array}{l}23.4 \\
(1.5)\end{array}$ & $\begin{array}{l}27.5 \\
(2.4)\end{array}$ \\
\hline Chloroplast lipid $\mathrm{V}_{\mathrm{v}}$ & $\begin{array}{c}0.9 \\
(0.2)\end{array}$ & $\begin{array}{c}1.0 \\
(0.1)\end{array}$ & $\begin{array}{c}0.7 \\
(0.1)\end{array}$ & $\begin{array}{c}0.6 \\
(0.1)\end{array}$ & $\begin{array}{c}0.9 \\
(0.2)\end{array}$ & $\begin{array}{c}0.9 \\
(0.2)\end{array}$ & $\begin{array}{c}0.5 \\
(0.2)\end{array}$ & $\begin{array}{c}0.1 \\
(0.2)\end{array}$ & $\begin{array}{c}0.8 \\
(0.2)\end{array}$ & $\begin{array}{l}1.0 \\
(0.2)\end{array}$ \\
\hline Mitochondria $V_{v}$ & $\begin{array}{c}4.2 \\
(0.6)\end{array}$ & $\begin{array}{c}3.8 \\
(0.6)\end{array}$ & $\begin{array}{c}3.9 \\
(0.4)\end{array}$ & $\begin{array}{c}5.0 \\
(0.9)\end{array}$ & $\begin{array}{c}3.4 \\
(0.5)\end{array}$ & $\begin{array}{c}4.4 \\
(0.8)\end{array}$ & $\begin{array}{c}4.6 \\
(0.6)\end{array}$ & $\begin{array}{c}4.2 \\
(0.5)\end{array}$ & $\begin{array}{c}4.4 \\
(0.8)\end{array}$ & $\begin{array}{c}6.8 \\
(0.8)\end{array}$ \\
\hline $\begin{array}{l}\text { Autophagic-like } \\
\text { vacuole } V_{v}\end{array}$ & $\begin{array}{c}0.5 \\
(0.2)\end{array}$ & $\begin{array}{c}0.5 \\
(0.3)\end{array}$ & $\begin{array}{c}0.5 \\
(0.1)\end{array}$ & $\begin{array}{c}0.3 \\
(0.2)\end{array}$ & $\begin{array}{c}0.1 \\
(0.1)\end{array}$ & $\begin{array}{c}0.6 \\
(0.2)\end{array}$ & $\begin{array}{c}0.2 \\
(0.1)\end{array}$ & $\begin{array}{c}0.9 \\
(0.4)\end{array}$ & $\begin{array}{c}0.5 \\
(0.2)\end{array}$ & $\begin{array}{c}1.3 \\
(0.4)\end{array}$ \\
\hline Lipid $V_{v}$ & $\begin{array}{c}4.1 \\
(0.1)\end{array}$ & $\begin{array}{c}6.4 \\
(1.7)\end{array}$ & $\begin{array}{c}6.8 \\
(1.6)\end{array}$ & $\begin{array}{c}5.9 \\
(1.5)\end{array}$ & $\begin{array}{l}10.7 \\
(3.3)\end{array}$ & $\begin{array}{l}13.6 \\
(1.9)\end{array}$ & $\begin{array}{l}10.3 \\
(1.6)\end{array}$ & $\begin{array}{c}7.7 \\
(1.8)\end{array}$ & $\begin{array}{c}8.8 \\
(1.9)\end{array}$ & $\begin{array}{c}7.0 \\
(1.3)\end{array}$ \\
\hline Vacuole $\mathrm{V}_{\mathbf{v}}$ & $\begin{array}{l}16.0 \\
(1.5)\end{array}$ & $\begin{array}{l}12.7 \\
(1.1)\end{array}$ & $\begin{array}{l}19.9 \\
(1.7)\end{array}$ & $\begin{array}{l}12.9 \\
(1.6)\end{array}$ & $\begin{array}{l}19.6 \\
(2.6)\end{array}$ & $\begin{array}{l}22.4 \\
(1.8)\end{array}$ & $\begin{array}{l}14.8 \\
(1.1)\end{array}$ & $\begin{array}{l}15.5 \\
(1.5)\end{array}$ & $\begin{array}{l}13.8 \\
(1.0)\end{array}$ & $\begin{array}{l}18.1 \\
(1.7)\end{array}$ \\
\hline Other & $\begin{array}{l}19.3 \\
(1.2)\end{array}$ & $\begin{array}{l}17.6 \\
(1.8)\end{array}$ & $\begin{array}{l}13.9 \\
(1.0)\end{array}$ & $\begin{array}{l}15.8 \\
(1.0)\end{array}$ & $\begin{array}{l}16.1 \\
(1.0)\end{array}$ & $\begin{array}{l}15.4 \\
(1.0)\end{array}$ & $\begin{array}{l}19.1 \\
(1.3)\end{array}$ & $\begin{array}{l}17.1 \\
(1.3)\end{array}$ & $\begin{array}{l}18.1 \\
(1.2)\end{array}$ & $\begin{array}{l}17.9 \\
(1.3)\end{array}$ \\
\hline Nucleus $V_{v}$ & $\begin{array}{l}18.4 \\
(2.7)\end{array}$ & $\begin{array}{l}17.2 \\
(2.0)\end{array}$ & $\begin{array}{l}15.7 \\
(2.3)\end{array}$ & $\begin{array}{l}17.0 \\
(1.9)\end{array}$ & $\begin{array}{c}9.6 \\
(2.3)\end{array}$ & $\begin{array}{c}7.7 \\
(1.9)\end{array}$ & $\begin{array}{l}15.9 \\
(2.7)\end{array}$ & $\begin{array}{l}14.8 \\
(2.4)\end{array}$ & $\begin{array}{l}16.0 \\
(2.3)\end{array}$ & $\begin{array}{c}9.8 \\
(2.7)\end{array}$ \\
\hline Frustulè $\cdot V_{v}$ & $\begin{array}{c}9.1 \\
(0.6)\end{array}$ & $\begin{array}{l}10.4 \\
(0.5)\end{array}$ & $\begin{array}{l}10.8 \\
(0.6)\end{array}$ & $\begin{array}{c}9.6 \\
(0.5)\end{array}$ & $\begin{array}{l}11.7 \\
(0.6)\end{array}$ & $\begin{array}{l}11.7 \\
(1.2)\end{array}$ & $\begin{array}{c}9.3 \\
(0.6)\end{array}$ & $\begin{array}{l}11.7 \\
(0.7)\end{array}$ & $\begin{array}{c}9.2 \\
(0.8)\end{array}$ & $\begin{array}{c}8.5 \\
(0.7)\end{array}$ \\
\hline Polyphosphate $V_{v}$ & $\begin{array}{c}0.8 \\
(0.2)\end{array}$ & $\begin{array}{c}1.3 \\
(0.4)\end{array}$ & $\begin{array}{c}0.6 \\
(0.1)\end{array}$ & $\begin{array}{c}1.9 \\
(0.5)\end{array}$ & $\begin{array}{c}2.2 \\
(0.5)\end{array}$ & $\begin{array}{c}0.9 \\
(0.4)\end{array}$ & $\begin{array}{c}2.2 \\
(0.5)\end{array}$ & $\begin{array}{c}1.6 \\
(0.4)\end{array}$ & $\begin{array}{c}2.0 \\
(0.4)\end{array}$ & $\begin{array}{c}1.7 \\
(0.3)\end{array}$ \\
\hline Fibrous vacuole $V_{v}$ & $\begin{array}{c}0.3 \\
(0.3)\end{array}$ & $\begin{array}{c}1.9 \\
(0.6)\end{array}$ & $\begin{array}{c}2.0 \\
(0.7)\end{array}$ & $\begin{array}{l}5.7 \\
(1.2)\end{array}$ & $\begin{array}{c}0.8 \\
(0.5)\end{array}$ & $\begin{array}{c}1.2 \\
(0.6)\end{array}$ & $\begin{array}{l}1.6 \\
(0.7)\end{array}$ & $\begin{array}{c}1.0 \\
(0.4)\end{array}$ & $\begin{array}{c}3.0 \\
(1.1)\end{array}$ & $\begin{array}{c}0.4 \\
(0.2)\end{array}$ \\
\hline $\begin{array}{c}\text { Chloroplast } N_{V} \\
\left(/ \mu m^{3} \text { cell }\right)\end{array}$ & $\begin{array}{c}0.19 \\
(0.01)\end{array}$ & $\begin{array}{c}0.13 \\
(0.01)\end{array}$ & $\begin{array}{c}0.21 \\
(0.03)\end{array}$ & $\begin{array}{c}0.14 \\
(0.02)\end{array}$ & $\begin{array}{c}0.12 \\
(0.02)\end{array}$ & $\begin{array}{c}0.11 \\
(0.04)\end{array}$ & $\begin{array}{c}0.17 \\
(0.03)\end{array}$ & $\begin{array}{c}0.12 \\
(0.02)\end{array}$ & $\begin{array}{c}0.17 \\
(0.04)\end{array}$ & $\begin{array}{c}0.16 \\
(0.02)\end{array}$ \\
\hline $\begin{array}{r}\text { Chloroplast lipid } \mathrm{N}_{\mathrm{V}} \\
\left(/ \mu \mathrm{m}^{3} \text { chloroplast }\right)\end{array}$ & $\begin{array}{l}26.17 \\
(6.00)\end{array}$ & $\begin{array}{l}18.90 \\
(4.00)\end{array}$ & $\begin{array}{l}25.21 \\
(5.11)\end{array}$ & $\begin{array}{l}21.29 \\
(4.60)\end{array}$ & $\begin{array}{l}21.49 \\
(2.40)\end{array}$ & $\begin{array}{l}32.65 \\
(1.33)\end{array}$ & $\begin{array}{l}47.37 \\
(3.50)\end{array}$ & $\begin{array}{l}23.53 \\
(5.30)\end{array}$ & $\begin{array}{r}69.63 \\
(4.6)\end{array}$ & $\begin{array}{l}50.24 \\
(1.34)\end{array}$ \\
\hline $\begin{array}{l}\text { Mitochondria } \mathrm{N}_{\mathrm{v}} \\
\left(/ \mu \mathrm{m}^{3} \text { cell }\right)\end{array}$ & $\begin{array}{c}0.08 \\
(0.02)\end{array}$ & $\begin{array}{c}0.05 \\
(0.02)\end{array}$ & $\begin{array}{c}0.11 \\
(0.02)\end{array}$ & $\begin{array}{c}0.10 \\
(0.02)\end{array}$ & $\begin{array}{c}0.07 \\
(0.02)\end{array}$ & $\begin{array}{c}0.08 \\
(0.02)\end{array}$ & $\begin{array}{c}0.15 \\
(0.02)\end{array}$ & $\begin{array}{c}0.07 \\
(0.01)\end{array}$ & $\begin{array}{c}0.08 \\
(0.01)\end{array}$ & $\begin{array}{c}0.08 \\
(0.02)\end{array}$ \\
\hline $\begin{array}{l}\text { Polyphosphate } \mathrm{N}_{\mathrm{V}} \\
\quad\left(/ \mu \mathrm{m}^{3} \text { cell }\right)\end{array}$ & $\begin{array}{c}0.34 \\
(0.13)\end{array}$ & $\begin{array}{c}0.52 \\
(0.23)\end{array}$ & $\begin{array}{c}1.19 \\
(0.40)\end{array}$ & $\begin{array}{c}0.49 \\
(0.15)\end{array}$ & $\begin{array}{c}0.76 \\
(0.22)\end{array}$ & $\begin{array}{c}0.92 \\
(0.45)\end{array}$ & $\begin{array}{c}0.49 \\
(0.29)\end{array}$ & $\begin{array}{c}0.39 \\
(0.16)\end{array}$ & $\begin{array}{c}0.65 \\
(0.20)\end{array}$ & $\begin{array}{c}1.11 \\
(0.45)\end{array}$ \\
\hline
\end{tabular}


GC/MS system, using the same DB5 column used in the GC/FID system and an Incos data acquisition system. The split mode was 5.4:1 with essentially the same temperature program as described above. The FAMEs were identified by use of the NBS/ EPA library with the exception of the C18:4 and C20:5 fatty acids which were not present in the library. These FAMEs were identified by visual examination and interpretation of the mass spectrum based on the fragmentation pattern of the FAMEs.

\section{Electron Microscopy}

Samples for electron microscopy were withdrawn into $50-\mathrm{ml}$ sterile polypropylene centrifuge tubes. Fixative and buffer were added to give final concentrations of $1 \%$ paraformaldehyde, $1 \%$ glutaraldehyde, and $0.05 \mathrm{M}$ cacodylate buffer at $\mathrm{pH} 7.2$ as previously described (Sicko-Goad and Lazinsky 1986). Samples were post-fixed in $1 \% \mathrm{OsO}_{4}$, dehydrated in a graded ethanol-propylene oxide series and embedded in Embed 812. Sections were cut with a diamond knife, collected on formvar coated 200 mesh copper grids, and stained with aqueous uranyl acetate (Watson 1958). Sections were examined and photographed with a JEOL JEM $100 \mathrm{~B}$ electron microscope operating at $80 \mathrm{kV}$. The morphometric sampling scheme used has been described in detail (Sicko-Goad et al. 1977, 1984, 1986) with precautions taken for unbiased sampling of unicells. The only exception to the previously described sampling scheme was that 25 photographs per individual treatment were examined. However, the point count per individual sample was ca 5,000, and standard errors were within $10 \%$ of the mean.

Cell volume estimates were determined by light microscopic measurements of epoxy mounts of fixed cells. Measurements of length and diameter were made of 25 cells for each treatment. Volumes were determined by assumption of a regular geometric shape by the relationship $V=d^{2} h / 4$.

\section{Results}

\section{Cytological Changes}

Summaries of the percent composition (relative volume) of each measured cellular compartment at all sampling times are presented graphically in Figure 1 and in tabular form (Table 1). Figure 1 demonstrates that the most prominent cellular changes that occur on exposure to 1,2,4-trichlorobenzene are an increase in lipid volume and a decrease in nuclear volume at $8 \mathrm{hr}$ of exposure. Although this sample was withdrawn in the dark and previous data (Sicko-Goad et al. 1988) suggest that these changes are associated with daily photoperiodic effects, it is apparent that exposure to this chlorinated benzene enhances the dark period effect. During the first hour of exposure, polyphosphate increases. Vacuole relative volume increases at 8 hours of exposure and remains elevated over control cells. Autophagic-like vacuole also increases at $8 \mathrm{hrs}$ of exposure and remains elevated in exposed cells. There is a significant increase in mitochondrial relative volume at $1 \mathrm{hr}, 24 \mathrm{hr}$, and 5 days of exposure, generally accompanied by a reduction in numbers per volume. The most pronounced changes in relative volumes of membranous organelles (chloroplast, mitochondria, and vacuole) occur at 5 days (Figure 2). The largest increases in fibrous vacuole and lipid are observed during the first $8 \mathrm{hr}$ of exposure. Reductions in these compartments are observed in later sampling periods (Table 1).

When data are regrouped into four major cellular compartments (Nucleus, Frustule, Vacuole, and Cytoplasm) with regrouping as follows (Vacuole $=$ empty vacuole + lipid + polyphosphate, and cytoplasm $=$ chloroplast, plastoglobuli, mitochondria, autophagic-like vacuole, other, and fibrous vacuole), the increase in vacuole volume due to lipid increase and the corresponding decrease in nuclear volume at 8 hours are more obvious (Figure 3).

There is no significant change in chloroplast numbers with exposure to the 1,2,4-isomer, although there is a trend of slight reduction with exposure (Figure 4). In general, polyphosphate bodies increase somewhat in exposed cells while mitochondrial numbers remain relatively constant. There is also a general increase in numbers of lipid droplets with culture age; the largest numbers are found in the oldest cells. However, exposure to the $1,2,4-$ isomer consistently reduces the number of plastoglobuli.

To further discriminate changes occurring in morphological composition with exposure, deviations (either increases or decreases) from the control cells were determined for all components for individual sampling periods. Significant changes reported below are changes which are $20 \%$ or greater for individual components when compared with control cultures of the same time period. This number was chosen since the standard errors of the mean were generally considerably less than $10 \%$ for larger, more conservative categories, and we felt that a conservative estimate of significance at the 95\% level would be associated with component changes of this magnitude or greater. Summaries of significant changes (Table 1) are as follows:

10 minutes-Increases in lipid, polyphosphate, and fibrous vacuole; decrease in central vacuole. 1 hour-Increases in mitochondria, polyphosphate, and fibrous vacuole; decrease in central vacuole and autophagic-like vacuolar inclusions. 8 hour-Increases in mitochondria, autophagiclike vacuole, lipid, and fibrous vacuole; decreases in polyphosphate and nucleus.

24 hour-Increases in autophagic-like vacuole and frustule; decreases in lipid, chloroplast lipid, polyphosphate, and fibrous vacuole. 

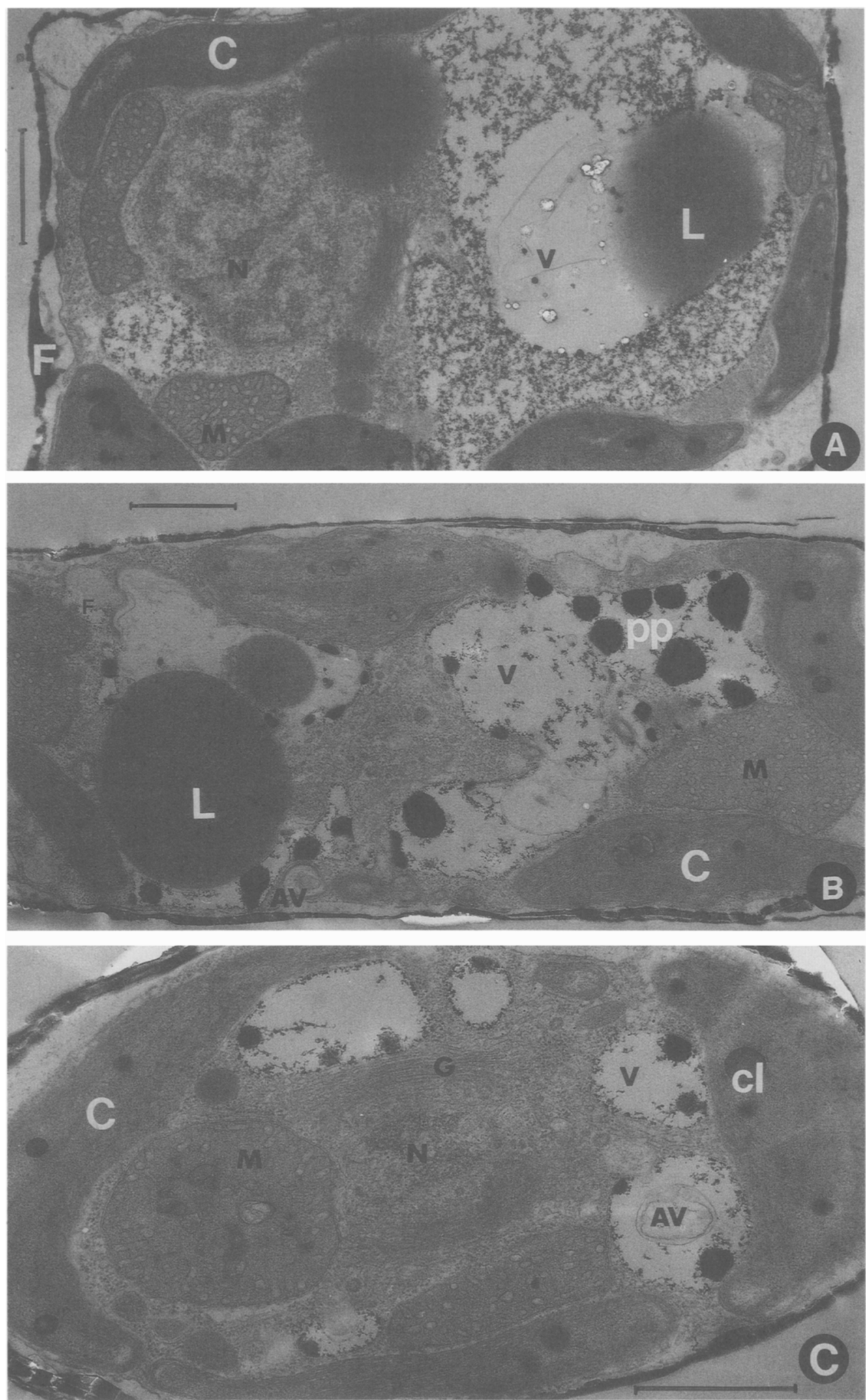

Fig. 2. Control and experimental cells of Cyclotella meneghiniana. Key to labelling: Autophagic-like Vacuole (AV), Chloroplast (C), Plastoglobuli (cl), Fibrous Vacuole (FV), Frustule (F), Golgi (G), Lipid (L), Mitochondria (M), Nucleus (N), Polyphosphate (pp), Vacuole (V). Marker bars $=1 \mu \mathrm{m}$. A Five day control cell showing typical cytoplasmic arrangement in diatoms with portions of nucleus and chloroplasts present. B Five day exposed cell showing a larger proportion of vacuole and increased membranous aggregates and vesiculation. Mitochondria are enlarged. C Five day exposed cell showing enlarged mitochondria with some vesiculation. Membranous aggregates (AV) and fibrous vacuoles (FV) are also obvious 


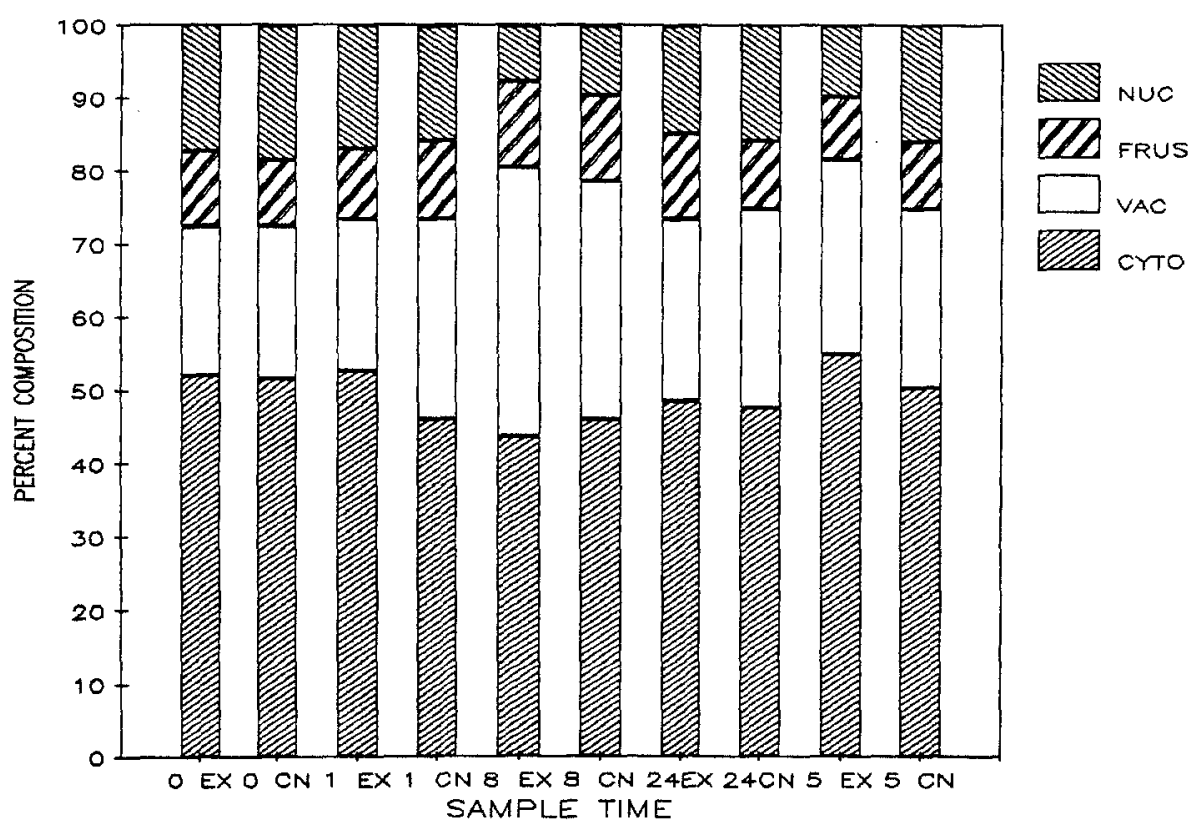

Fig. 3. Recalculation of major cellular compartments demonstrating total vacuole volume, including lipid

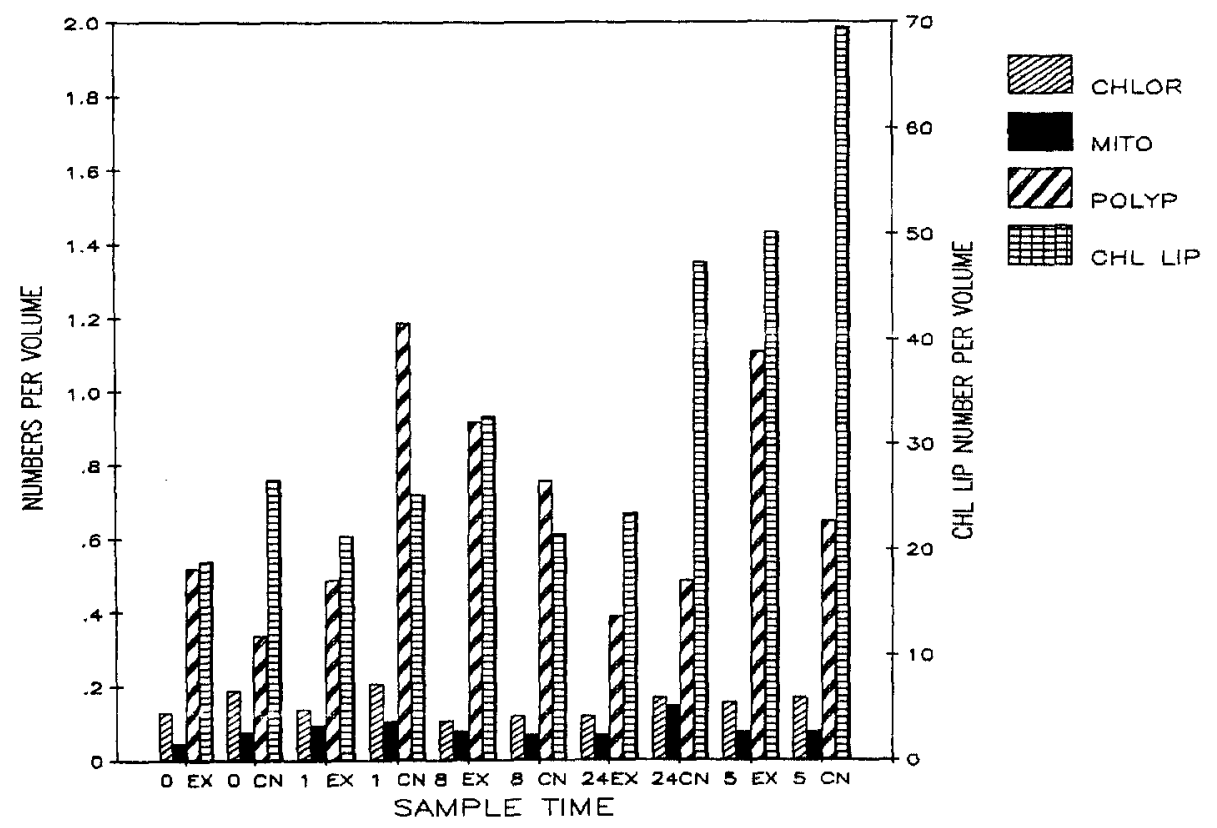

Fig. 4. Changes in numbers per volume $\left(\mathrm{N}_{\mathrm{v}}\right)$ with sample time and treatment. Chloroplast lipid $\mathrm{N}_{\mathrm{v}}$ calculation is based on numbers per $\mu \mathrm{m}^{3}$ chloroplast. All other categories are per $\mu \mathrm{m}^{3}$ cell
5 day-Increases in chloroplast lipid, mitochondria, autophagic-like vacuole, and central vacuole; decreases in nucleus, lipid, and fibrous vacuole.

\section{Fatty Acid Composition}

C16 fatty acids predominate in C. meneghiniana (Figure 5). With exposure to 1,2,4-trichlorobenzene, there appears to be a long-term decline in the
C16:0 fatty acid accompanied by an overall increase in the C16:1 fatty acid. Minor fatty acids increase with age; however, they are present in higher concentrations in control cells. Changes in other fatty acids were monitored in a fashion similar to that used for the morphological components. That is, percent change as an increase or decrease compared with controls was plotted for individual fatty acids against sample time. Summaries of changes that were greater than $20 \%$ as previously described are as follows: 


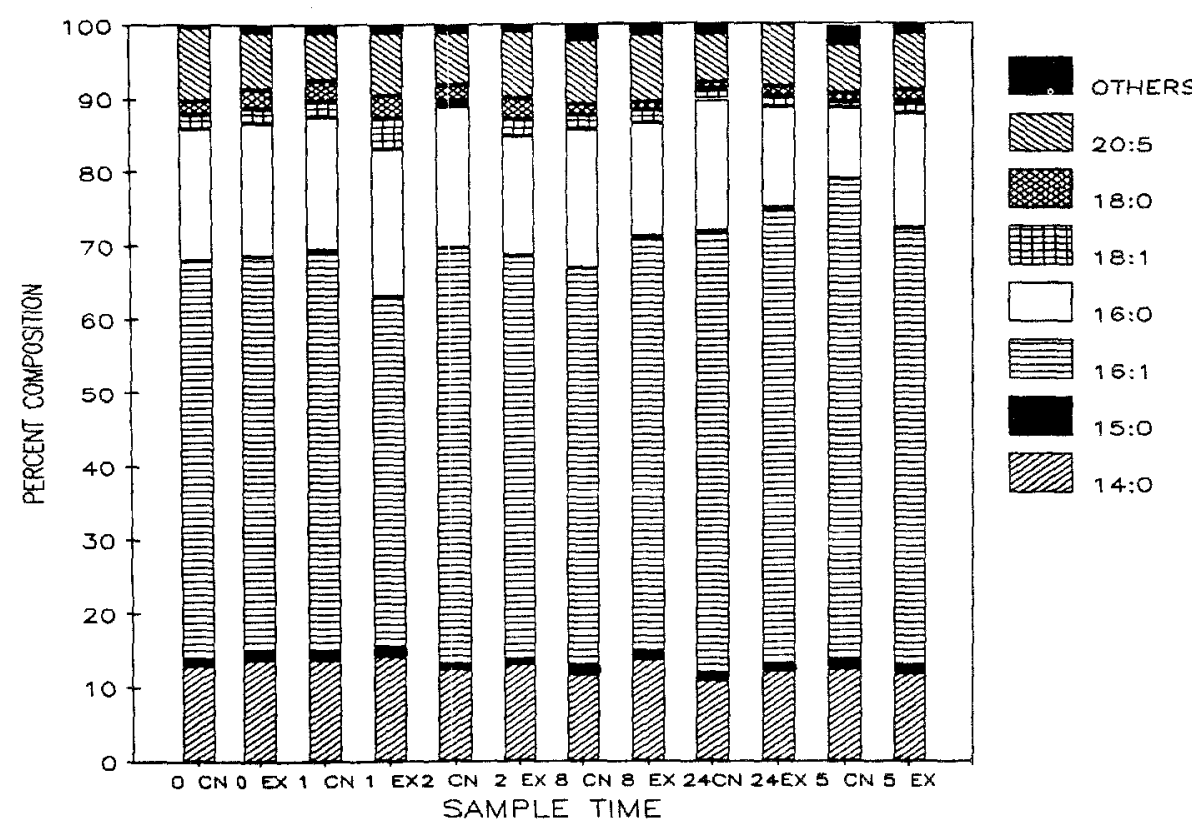

Fig. 5. Change in fatty acid percent composition with treatment. Minor fatty acids (less than 1\%) represented by the category others include C13(12methyl):0, C14(12methyl):0, C17:0, C18:4, C18:2, C19:0, C20:0, $\mathrm{C} 22: 0, \mathrm{C} 23: 0$
10 minutes-Increases in C15:0, C18:0; Decrease in $\mathrm{C} 20: 5$ (Figure 6a).

1 hour-Increases in C18:1 and C20:5 (Figure 6b).

8 hour-Decrease in C16:0 (Figure 6c).

24 hour-Decreases in C16:0; Increases in C18:0 and C20:5 (Figure 7a).

5 day-Increases in C16:0, C18:1, and C18:0 (Figure 7b).

A total of 41 significant changes in morphological components (relative volumes and numbers per volume) and 12 significant changes in fatty acid percent composition were observed in the five sampling periods. The number of significant changes increased with exposure time.

\section{Discussion}

Previous work (Sicko-Goad et al. 1988) has demonstrated that cultures of Cyclotella meneghiniana exhibit a moderate degree of division synchrony in that cells divide during the latter half of the light/ dark cycle. Changes that occur in the daily photoperiod in both cytological and fatty acid composition are advantageous to sustain cell division and metabolism in the absence of light and consequent loss of the production of energy-rich compounds during photosynthesis. For example, Atkinson et al. (1974) reported that starch reserves of Chlorella fusca var. vacuolata are depleted during cytokinesis which occurs in this organism in the dark. These authors also noted that the first starch to dis- appear was that located adjacent to the pyrenoid and consumption began during the last few hours of photosynthesis before the onset of dark. Similarly, Puiseux-Dao (1981) noted an increase in chloroplast lipid droplets at the beginning of the light period. More recently, Wada et al. (1987) demonstrated the diurnal appearance of fatty particles in Heterosigma akashiwo, a dominant red tide raphidophycean biflagellate, with degradation of these particles occuring in the dark just prior to cell division. In Cyclotella, both vacuolar and chloroplast lipid reserves are highest during the early part of the dark period and lowest in the early light period. In terms of assessing the effect of lipophilic toxicants on organisms having such cyclical changes in lipid content, the timing of measurement of response becomes critical when one is attempting to evaluate subtle, nonlethal doses.

The fact that one of our samples was withdrawn during the dark period of the daily photoperiod was serendipitous. Yet without that sample ( $8 \mathrm{hr}$ of exposure), we would have no way of demonstrating either the increase in lipid volume that occurred in the dark period, or the changes in fatty acid percent composition that are indicative of photosynthesis. For example, Kates and Volcani (1966) suggested that the requirement for photosynthesis is for a certain degree of unsaturation, and in diatoms, the most likely candidate, since diatoms generally lack linolenic acid (DeMort et al. 1972), is the C20:5 fatty acid. In Cyclotella (Sicko-Goad et al. 1988), this fatty acid increases late in the late light period, reaches its maximum in the dark, and is at its lowest levels in the early part of the light period, 

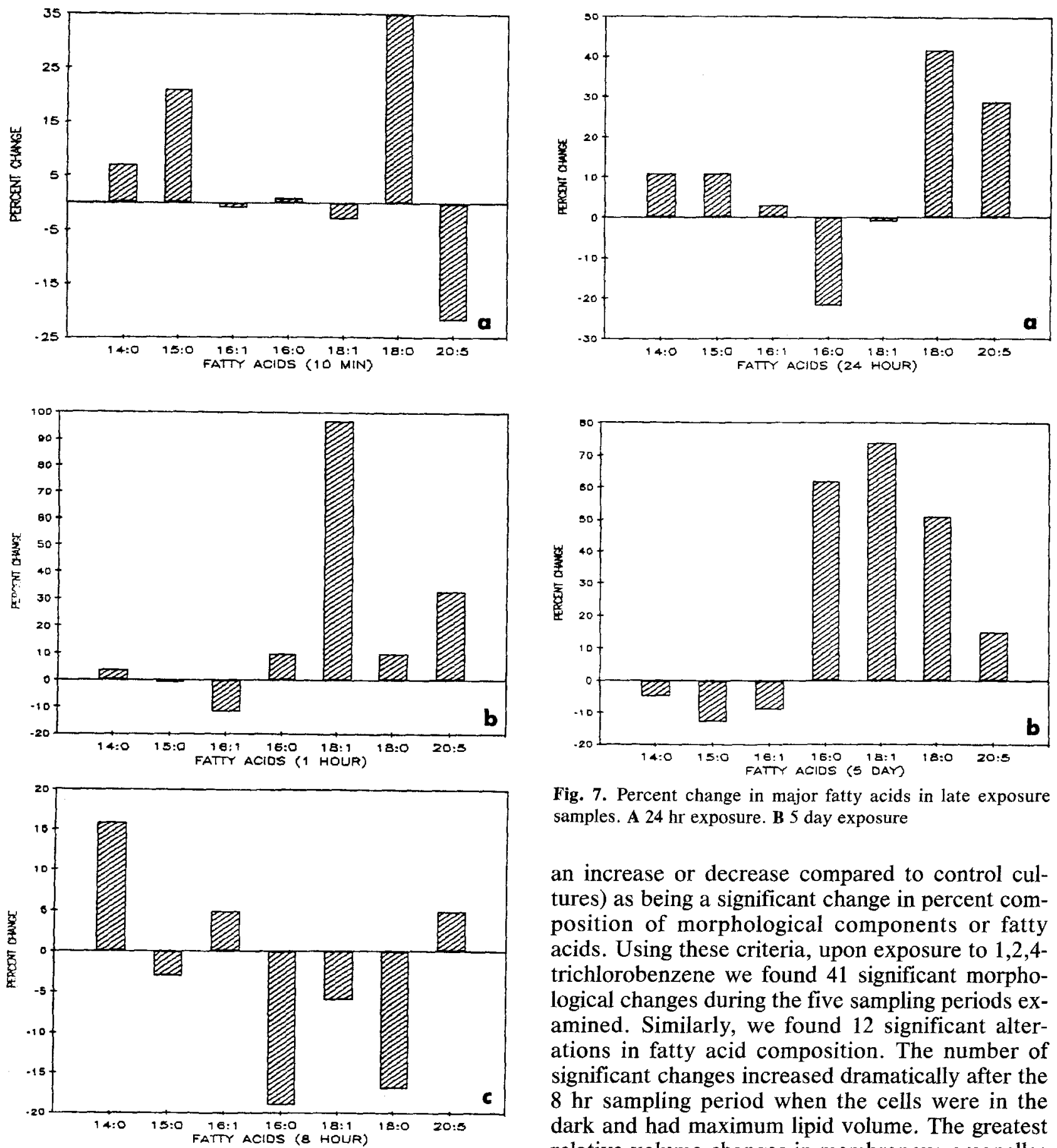

Fig. 6. Percent change in major fatty acids on exposure to 1,2,4trichlorobenzene. A $10 \mathrm{~min}$ exposure. B $1 \mathrm{hr}$ exposure. C $8 \mathrm{hr}$ exposure

when photosynthesis is generally at its maximum rate.

These data (Sicko-Goad et al. 1988) suggested that cell cycle events may either mitigate or amplify effects of lipophilic toxicants, and data presented here would tend to support this theory. For example, we defined earlier a $20 \%$ change (as either

Fig. 7. Percent change in major fatty acids in late exposure samples. A $24 \mathrm{hr}$ exposure. B 5 day exposure

an increase or decrease compared to control cultures) as being a significant change in percent composition of morphological components or fatty acids. Using these criteria, upon exposure to 1,2,4trichlorobenzene we found 41 significant morphological changes during the five sampling periods examined. Similarly, we found 12 significant alterations in fatty acid composition. The number of significant changes increased dramatically after the $8 \mathrm{hr}$ sampling period when the cells were in the dark and had maximum lipid volume. The greatest relative volume changes in membranous organelles occurred during the $24 \mathrm{hr}$ and 5 day sampling periods. The changes that occurred early in the sampling scheme were primarily changes in storage products. The increase in storage product accumulation due to nutrient stress or toxicant exposure has been reported many times (Fogg 1956; SickoGoad and Stoermer 1979; Shifrin and Chisholm 1981; Varum and Mykelstad 1984; Smith and Geider 1985; Millie 1986; Sicko-Goad and Lazinsky 1986; Sicko-Goad et al. 1986). Consequently, this short-term effect was not unexpected. 
These changes suggest that lipid-rich cells are less vulnerable to the effects of lipophilic toxicants, and reexposure to more favorable growth condition, when lipid reserves are metabolized, may result in mobilization of these toxicants. Lipid reserves may thus explain the delayed and/or longterm effects of lipophilic toxicants on phytoplankton populations. Although the relationship between lipid content and persistent lipophilic toxicants has been recognized for animals (Goerke et al. 1979; Goerke 1984; Geyer et al. 1985), little research has been reported examining this relationship for aquatic microorganisms.

Acknowledgments. We are grateful to Dr. S. S. Kilham for kindly providing the culture of Cyclotella. Supported by grant R-810684 from the Office of Exploratory Research, the United States Environmental Protection Agency. Contribution No. 498 of the Great Lakes Research Division.

\section{References}

Atkinson AW Jr, John PCL, Gunning BES (1974) The growth and division of the single mitochondrion and other organelles during the cell cycle of Chlorella, studied by quantitative stereology and three dimensional reconstruction. Protoplasma 81:77-109

DeMort CL, Lowry R, Tinsley I, Phinney HK (1972) The biochemical analysis of some estuarine phytoplankton species. I. Fatty acid composition. J Phycol 8:211-216

Fogg GE (1956) Photosynthesis and formation of fats in a diatom. Ann Bot 20:265-285

Galassi S, Vighi M (1981) Testing toxicity of volatile substances with algae. Chemosphere 10:1123-1126

Geyer H, Politzki G, Freitag D (1984) Prediction of ecotoxicological behaviour of chemicals; Relationship between $n-O c$ tanol/water partition coefficient and bioaccumulation of organic chemical by algae Chlorella. Chemosphere 13:269284

Geyer H, Scheunert I, Korte F (1985) Relationship between the lipid content of fish and their bioconcentration potential of 1,2,4-trichlorobenzene. Chemosphere 14:545-555

Gibson DT (1976) Initial reactions in the bacterial degradation of aromatic hydrocarbons. Zentralbl Bakteriol Hyg $1 \mathrm{Abt}$ Orig $162: 157-168$

Goerke $H$ (1984) Temperature dependent elimination of $2,4,6,2^{\prime}, 4^{\prime}$,-pentachlorobiphenyl in Nereis virens (Polychaeta). Arch Environ Contam Toxicol 13:347-355

Goerke H, Eder G, Weber K, Ernst W (1979) Patterns of organochlorine residue in animals of different trophic levels from the Weser Estuary. Mar Pollut Bull 10:127-133

Guillard RRL (1975) Culture of phytoplankton for feeding marine invertebrates. In Smith WL, Chaney MH (eds) Culture of Marine Invertebrate Animals. Plenum, New Yotk. pp $39-59$

Halfon E, Reggiani MG (1986) On ranking chemicals for environmental hazard. Environ Sci Technol 20:1173-1179

Kates M, Volcani BE (1966) Lipid composition of diatoms. Biochim Biophys Acta 116:264-278

Lu P, Metcalf RL (1975) Environmental fate and biodegrad- ability of benzene derivatives as studied in a model aquatic ecosystem. Environ Health Perspect 10:269-284

Matsuo M (1980) The i/o (inorganic/organic)-characters to correlate bioaccumulation of some chlorobenzenes in guppies with their chemical structure. Chemosphere 9:409-413

Metcalfe LD, Schmitz AA (1961) The rapid preparation of fatty acid esters for gas chromatographic analysis. Anal Chem $33: 363-364$

Milie DF (1986) Nutrient-limitation effects on the biochemical composition of Cyclotella meneghiniana (Bacillariophyta): an experimental and statistical analysis. Can J Bot 64:19-26

Neely WB, Branson DR, Blau GE (1974) Partition coefficient to measure bioconcentration potential of organic chemicals in fish. Environ Sci Technol 8:1113-1115

Puiseux-Dao S (1981) Cell-cycle events in unicellular algae. Can Bull Fish Aquat Sci 210:130-149

Schwarzenbach RP, Fisher NS (1978) Rapid determination of the molecular weight distribution of total cellular fatty acids using chemical ionization mass spectrometry. J Lipid Res 19:12-17

Shifrin NS, Chisholm SW (1981) Phytoplankton lipids: interspecific differences and effects of nitrate, silicate, and lightdark cycles. J Phycol 17:374-384

Sicko-Goad L, Lazinsky D (1986) Quantitative ultrastructural changes associated with lead-coupled luxury phosphate uptake and polyphosphate utilization. Arch Environ Contam Toxicol 15:617-627

Sicko-Goad L, Stoermer EF (1979) A morphometric study of lead and copper effects on Diatoma tenue v. elongatum (Bacillariophyta). J Phycol 15:316-321

Sicko-Goad L, Ladewski BG, Lazinsky D (1986) Synergistic effects of nutrients and lead on the quantitative ultrastructure of Cyclotella (Bacillariophyceae). Arch Environ Contam Toxicol 15:291-300

Sicko-Goad L, Simmons MS, Lazinsky D, Hall J (1988) Effect of light cycle on diatom fatty acid composition and quantitative morphology. J Phycol 24:1-7

Sicko-Goad L, Stoermer EF, Ladewski BG (1977) A morphometric method for correcting phytoplankton cell volume estimates. Protoplasma 93:147-163

Sicko-Goad L, Stoermer EF, Schelske CL (1984) Estimation of intracellular carbon and silica content of diatoms from natural assemblages using morphometric techniques. Limnol Oceanogr 29:1170-1178

Smith RE, Geider RJ (1985) Kinetics of intracellular carbon allocation in a marine diatom. J Exp Mar Biol Ecol 93:191-210

Varum KM, Myklestad S (1984) Effects of light, salinity and nutrient limitation on the production of B-1,3-D-Glucan and Exo-D-Glucanase activity in Skeletonema costatum (Grev.) Cleve. J Exp Mar Biol Ecol 83:13-25

Wada M, Hara Y, Kato M, Yamada M, Fujii T (1987) Diurnal appearance, fine structure, and chemical composition of fatty particles in Heterosigma akashiwo (Raphidophyceae). Protoplasma 137:134-139

Watson ML (1958) Staining tissue sections for electron microscopy with heavy metals. J Biophys Biochem Cytol 4:475478

Williams RT, Hiron PC, Renwick AG (1975) Species variation in the metabolism of some organic halogen compounds. In Ecological Toxicology Research, Effects of Heavy Metal and Organohalogen Compounds. Plenum Press, New York, pp 91-106

Manuscript received February 2, 1988. 